\title{
Maria Czaplicka-Jedlikowska, Edukacyjne aspekty nazw własnych w literaturze dla dzieci, Wydawnictwo Uniwersytetu Kazimierza Wielkiego, Bydgoszcz 2007, ss. 288
}

W książce Marii Czaplickiej-Jedlikowskiej scalają się dwa wcześniejsze nurty badań autorki: onomastyczno-literacki i dotyczący onomastyki w dydaktyce szkolnej. Jest to - co należy podkreślić - pierwsza, tak obszerna praca poświęcona onimii w utworach dla dzieci, a zarazem pierwsze opracowanie realizujące wysuwane już w latach osiemdziesiątych XX wieku postulaty łączenia onomastyki uzualnej i literackiej z dydaktyką szkolną ${ }^{1}$.

Książka składa się z dziesięciu rozdziałów, z których cztery (III, IV, V, VI) mają charakter autonomicznych (onomastyczno-literackich) opracowań nazewnictwa w utworach dla dzieci: Marii Konopnickiej, Marii Kownackiej, Ewy Szelburg-Zarembiny, Wandy Chotomskiej. W obszarze kontrastywnej (porównawczej) onomastyki literackiej sytuuje się rozdział VII poświęcony zagadnieniu onimizacji prezentowanemu na przykładzie tekstów Janiny Porazińskiej i Danuty Wawiłow. Wskazaną część książki stanowią przeróbki artykułów opublikowanych przez autorkę w latach 1998-2007². Rozdziały napisane

${ }^{1}$ Zob. artykuły zebrane w tomie: Onomastyka w dydaktyce szkolnej i społecznej. Materiaty z VI Ogólnopolskiej Konferencji Onomastycznej, red. E. Homa, Szczecin 1988.

${ }^{2}$ Zob. M. Czaplicka-Niedbalska, Nazwy własne w utworach Marii Kownackiej, w: Przemiany i przyszłość pedagogiki wczesnoszkolnej, red. E. Stucki, Bydgoszcz 1998, s. 151-161; eadem, Walory wychowawcze nazw własnych w wybranych utworach M. Kownackiej i E. Szelburg-Zarembiny, w: Literatura i sztuka a wychowanie, red. J. Kida, Rzeszów 2001, s. 199-207; M. Czaplicka, Dydaktyczno-wychowawcza funkcja nazw własnych w literaturze dla dzieci na przykładzie twórczości Wandy Chotomskiej, w: Metodologia badań onomastycznych, red. M. Biolik, Olsztyn 2003, s. 473-484; por. też M. Czaplicka-Jedlikowska, Nazwy własne w literaturze dziecięcej i ich percepcja w świetle badań empirycznych a kształtowanie językowe dzieci 9-10-letnich, w: Kultura, literatura i sztuka w edukacji językowej $w$ świetle badań empirycznych, red. J. Kida, Rzeszów 2007, s. 234-252. 
na potrzeby tej książki to: rozdział I: Wprowadzenie (obejmujące dwa podrozdziały: Przedmiot analizy $i$ zakres przeprowadzonych badań oraz Założenia teoretyczne i metodologiczne), rozdział II: Literatura dla dzieci, jej miejsce $w$ kulturze $i$ w badaniach onomastycznych; rozdział IX: Teoretyczne aspekty edukacji językowej - rola hermeneutyki filozoficznej oraz Zakończenie. Pracę zamykają: Literatura przedmiotowa i podmiotowa, Rozwiqzania skrótów oraz aneksy obejmujące przygotowane przez autorkę testy (Test „A" na podstawie wybranych wierszy dla dzieci Juliana Tuwima i Test „B" wedtug opowiadania Marii Kownackiej „Kajtkowe przygody”), przeznaczone do badania percepcji i świadomości onomastycznej dzieci.

Artykułowa geneza znacznej części książki sprawia, że otrzymaliśmy całość sygnalizującąjedynie niektóre zagadnienia onimii w „literaturze osobnej”, za jaką uważa się do dziś literaturę dla dzieci. Wypada zgodzić się z autorką, że ,jednolity charakter tak skonstruowanej rozprawie nadaje: przedmiot badawczy - nazwy własne i ich deskrypcje jednostkowe w literaturze dla dzieci (zwracam uwagę na błędne sformułowanie „nazwy własne i ich deskrypcje jednostkowe”, zamiast „nazwy własne i deskrypcje jednostkowe” s. 14). Można - choć z podanymi niżej zastrzeżeniami - uznać, że o ,jednolitym charakterze" rozprawy decydują przyjęte założenia teoretyczno-metodologiczne oraz wytyczone cele badawcze. Przypomnę wstępne deklaracje autorki rozprawy: „Zakres pracy ma zasadniczo dwojaki wymiar: materiałowo-badawczy i teoretyczno-metodologiczny. Pierwszy z nich to opis językowo-kulturowy nazw z wybranych utworów dla dzieci. Drugi to rozważania teoretyczno-metodologiczne z dziedziny językoznawstwa i onomastyki w aspekcie edukacyjnym" (s. 14). Deklaracje te pozwalają rozumieć cele pracy jako: teoretyczne i stosowane.

Osobna uwaga należy się decyzjom autorki w kwestii doboru tekstów do części analitycznej pracy oraz przyjętej metodzie badawczej. Podjęcie badań onomastyczno-literackich przez onomastę (językoznawcę) wymaga przede wszystkim deklaracji w kwestii rozumienia terminów: literatura (tu: literatura dla dzieci) i - ze względu na zakreślany w pracy horyzont odwołań hermeneutycznych - literackość. Uzasadnienia wymaga również dobór tekstów stanowiących podstawę szczegółowych analiz, na których badacz zamierza wesprzeć konstrukcję teoretyczną. Kwestia pierwsza (rozumienie literatury dla dzieci) zostaje szczegółowo omówiona w pracy. Co do następnych - o ile jako przekonujące można potraktować uzasadnienie, że „Wybór autorek został podyktowany osadzeniem ich twórczości w różnych nurtach literackich i różnych okresach historii literatury, odmiennością w posługiwaniu się materiałem językowym i różnicach $\mathrm{w}$ kreacji świata przedstawionego oraz w dialogu z podmiotem lirycznym" (s. 14), o tyle dziwić musi brak informacji o kryte- 
riach selekcji tekstów wybranych autorek. Być może ów wybór tłumaczy kanon lektur szkolnych dzieci 9-, 10-letnich, ale wyjaśnień na ten temat brakuje w pracy. Wskazany przedział wiekowy autorka wyodrębnia jako samodzielna całość w procesie edukacyjnym, realizującą charakterystyczne cele i zadania (tego przedziału wiekowego uczniów dotyczą też formułowane w pracy wskazania metodyczne dla nauczycieli).

Geneza artykułowa pierwszej części rozprawy (prace autorki drukowane w latach 1998-2007) - decyduje o wyraźnie zauważalnej w książce ewolucji metody badawczej: początkowo funkcjonalnej i odwołań głównie do monografii Aleksandra Wilkonia ${ }^{3}$, później do prac autorów korzystających w analizach onomastyczno-literackich $\mathrm{z}$ osiagnięć tekstologii i antropologii kulturowej. Analiza funkcjonalna pozwala autorce wskazać funkcje onimii w utworach dla dzieci: lokalizacyjnq (w czasie i przestrzeni), socjologicznq, treściowq, ekspresywnq i aluzyjna, a także dydaktycznq, wychowawczq, poetyckq i wartościujacq (s. 17). O specyfice literatury dziecięcej decyduje hierarchizacja tych funkcji. Jako prymarne jawią się autorce dydaktyczna i wychowawcza.

$\mathrm{W}$ ocenie sposobu interpretacji zjawisk onimicznych w literaturze dla dzieci proponowanego przez M. Czaplicką-Jedlikowską odnieść należy się do wskazywanej w książce expressis verbis perspektywy hermeneutycznej co można uznać za interesującą propozycję badawczą. Tego rodzaju wstępne deklaracje autorki (s. 32) pozwalały spodziewać się przynajmniej wytłumaczenia różnic między strukturalizmem i hermeneutyką w podejściu do języka (przywołania choćby Heideggerowskiego „die Sprache spricht”) i znaczenia (dla hermeneutów znaczenie powstaje $\mathrm{w}$ drodze interpretacji przez odniesienie go do własnej sytuacji egzystencjalnej interpretatora). Tymczasem, część pierwsza (analityczna) książki M. Czaplickiej-Jedlikowskiej nie wykazuje związku z pracami badawczymi podległymi zasadom hermeneutyki, zabrakło tu spodziewanej analizy stylistycznej typu hermeneutycznego. Nie spotykamy się $\mathrm{w}$ tej części pracy $\mathrm{z}$ konsekwentnym wykorzystaniem metodologii i teorii hermeneutycznej, lecz z postępowaniem interpretacyjnym noszącym jedynie pewne znamiona (cechy) hermeneutyki - autorka w trakcie analizy funkcjonalnej wspomina o możliwych (indywidualnych), zależnych od „horyzontów wiedzy", odczytaniach sensów nazw własnych przez dzieci.

Zapleczem teoretycznym tłumaczącym tok postępowania badawczego w rozprawie miał być - w założeniu autorki - ostatni rozdział zatytułowany Teoretyczne aspekty edukacji językowej - rola hermeneutyki filozoficznej. Był on konieczny dla uzasadnienia dychotomii funkcjonalnej nazewnictwa w literaturze dla dzieci. Dodam, że wskazywana obecnie m.in. przez badaczy

\footnotetext{
${ }^{3}$ A. Wilkoń, Nazewnictwo w utworach Stefana Żeromskiego, Wrocław 1970.
} 
niemieckich ${ }^{4}$ (deklarujących orientację hermeneutyczną) dychotomia Bildung 'kształcenie' i Formation 'formacja' może w aspekcie onimicznym przekładać się na funkcje: dydaktyczną i wychowawczą nazw własnych, której podporządkowana jest funkcja wartościująca nazw. Książka M. Czaplickiej-Jedlikowskiej pozwala niewątpliwie dostrzec wzajemną zależność tych funkcji. Odpowiada to rozumieniu wychowania jako nauczania i uczenia się, w sensie działań zmierzających nie tylko do pozyskania wiedzy i umiejętności, ale też celowego nabywania przez dziecko trwałych orientacji wartościujących. Poruszając edukacyjne aspekty nazw własnych w literaturze dla dzieci, Autorka ujmuje edukację w sensie hermeneutycznym, jako „kształcenie wynoszące ku człowieczeństwu", tj. ściśle związane z wartościami.

Przyznać trzeba, że na tle ostatniego rozdziału, część pierwsza pracy (analityczna) budzi wyraźny niedosyt. Analiza polegająca na wydobyciu funkcji onimów w konkretnych (w założeniu przykładowych, reprezentatywnych) tekstach dla dzieci jest w zasadzie realizacją pewnego algorytmu stwarzanego przez wybraną metodę onomastyczno-literackich badań funkcjonalnych, uprawianych w latach siedemdziesiątych-dziewięćdziesiątych ubiegłego wieku. Założona interpretacja hermeneutyczna onimii wiązać się powinna ściśle z przekonaniem, że podmiot interpretacji nie jest „stabilny” i ulega przemianom zależnie od historycznie zmiennej sytuacji, w którą jest uwikłany wraz $\mathrm{z}$ interpretowanym przedmiotem (tekstem). Istotne $\mathrm{w}$ tym przypadku kategorie: odbiorcy oraz czytania („lektury rozumiejącej”) służącego rozszerzaniu horyzontów wiedzy dziecka, nie zostały w części analitycznej pracy należycie wykorzystane.

Główny zrąb rozprawy stanowią rozdziały dotyczące kwestii edukacyjnych, to jest uwzględnienia w nauczaniu onomastyki uzualnej i literackiej. M. Czaplicka-Jedlikowska dowodzi, że treści edukacji w zakresie onomastyki (też onomastyki regionalnej) na poziomie wczesnoszkolnym komponują się $\mathrm{z}$ treściami kształcenia takich przedmiotów, jak: język polski, historia i społeczeństwo, przyroda (co znajduje odzwierciedlenie w Podstawach programowych). Analizując układ treści kształcenia, autorka dostrzega w nich miejsce dla onomastyki (nazwy osób związanych z regionem, nazwy miejsc związane z historią regionu i tradycją lokalna, onimia miejska, mikrotoponimia). Do proponowanych przez M. Czaplicką-Jedlikowską konkretnych działań dydaktycznych związanych z nauczaniem onomastyki dodałabym techniki wsparte na procedurach pragmalingwistycznych i socjolingwistycznych. W odniesieniu do antroponimii istotne znaczenie ma bowiem konieczność odróżniania

${ }^{4}$ Zob. G. Koss, Namenforschung. Eine Einführung in die Onomastik 3., aktualisierte Auflage, Tübingen 2002. 
takich poziomów, jak: oficjalność/nieoficjalność (prywatność, poufałość) czy zabarwienie uczuciowe nazw. Jeszcze inne obszary dydaktyki onomastycznej stanowią: etykieta językowa, onomastyka gwarowa, socjolektalna etc. ${ }^{5}$.

Książkę czyta się trudno ze względu na specyfikę pisarstwa Marii Czaplickiej-Jedlikowskiej. Zawiły tok wykładu, liczne cytaty i parafrazy spostrzeżeń innych badaczy (onomastów, teoretyków i krytyków literatury, filozofów), niestety, nie zawsze - co trzeba wyraźnie zasygnalizować - koherentne względem siebie, utrudniają śledzenie własnej myśli autorki bądź całkowicie ją eliminuja.

Podsumowując, pragnę podkreślić, że - mimo wskazanych niedociagnięć - jako pokazująca rolę onimii w edukacji książka M. Czaplickiej-Jedlikowskiej ma charakter pionierski. Pozostaje mieć nadzieję, że sformułowane w rozprawie spostrzeżenia dotyczące miejsca nazw własnych w dziele literackim i słowniku dziecka oraz propozycje kształcenia onomastycznego już na poziomie podstawowym zostaną w pełni wykorzystane w praktyce szkolnej.

Irena Sarnowska-Giefing

${ }^{5}$ Zob. I. Sarnowska-Giefing, Glos onomasty w sprawie nauczania słownictwa, w: Nauczanie języka polskiego jako obcego i polskiej kultury w nowej rzeczywistości europejskiej. Materiaty z VI Międzynarodowej Konferencji Glottodydaktycznej, red. P. Garncarek, Warszawa 2005, s. 183-192. 
